\title{
Deer and Cattle Diets on Summer Range in British Columbia
}

\author{
W. WILLMS, A. MCLEAN, R. TUCKER, AND R. RITCEY
}

\begin{abstract}
A study was made on the forage selection of mule deer and cattle on summer range in the Douglasfir zone. Both ungulates showed a high preference for clover, willow, and fireweed. When the availability of these forages was not limiting, the percent of diet overlap was high. As their availability declined, diet overlap decreased as both deer and cattle were forced into their individual food niche. For cattle the niche was grass, while for deer it was shrubs. The effect of declining availability of preferred forages on the dietary composition was less for deer than for cattle. Presumably the greater ability of deer to be selective permitted them to utilize those forages despite reduced availability.
\end{abstract}

The summer range of deer (Odocoileus hemionus hemionus) and cattle in south central British Columbia extends from about $900 \mathrm{~m}$ to 2,300 $\mathrm{m}$ elevation. This range includes the Douglasfir (Pseudotsuga menziesii), subalpine fir (Abies lasiocarpa), and alpine zones.

The range is large and the population density of deer and cattle over the entire area low. However, since both cattle and deer prefer open forests and clearings (Harris 1954; Gates 1968; Wallmo et al. 1972; Edgerton 1972), the area of habitat acceptable to both species is considerably less and the potential for competition increased.

Two studies on deer and cattle interactions have been reported for ranges similar to those of the present study (Skovlin et al. 1976; Julander 1955). They were designed to determine the effects of grazing by cattle on deer distribution and forage consumption. Conclusions varied between light to severe competition with little explanation of the variable effect.

Cattle diets on summer range in southern B.C. have been reported earlier (McLean and Willms 1977), however, little is known about the summer diets of deer on this range. This paper reports on several studies to evaluate the potential for forage competition between deer and cattle. In one study interaction was examined directly by enclosing both species within the same area. The information was supplemented in two other studies. In one, the degree of forb and shrub use by cattle was determined in relation to grazing intensity; in the other, forage selection by mule deer fawns was examined.

\section{Site Description}

The Opax study was about $15 \mathrm{~km}$ northwest of Kamloops, British Columbia, in the Douglasfir-pinegrass (Calamagrostis rubescens) community. The floristic composition has been described by McLcan (1970) and by Tisdale and McLean (1957). All work was done in forest openings, cleared by logging 10 to 15 years prior to the study.

\footnotetext{
Authors are research scientists, research technician, Agriculture Canada Research Station; and wildlife biologist, British Columbia Fish and Wildlife Branch, Kamloops, B.C.

Manuscript received July 7, 1978
}

The terrain was typically mountainous with elevations ranging from 1,065 to $1,340 \mathrm{~m}$ msl. Most of the work was done in a 3-ha site with gentle slopes locatcd at the base of a steep hill with a north aspect. A deer-proof fence surrounded the site and also bisected it into two fields of approximately equal areas. One field was used by deer only while the other field was used by both deer and cattle.

\section{Methods}

\section{Direct Interaction Study \\ Year One}

Four, 2-year-old mule deer and two heifers were used in the grazing trials. The deer were two castrates and two does. Grazing observations were made in two periods defined by grazing treatment. During the first period (July 9 to August 2) all four deer were in one field, for a stocking rate of 2.8 ha per AUM, and two heifers in the other field. During the second period (August 2 to August 31 ) there were two deer in the deer-only field and two deer in the cattle-grazed field (dualgrazcd field). The two heifers used the field periodically to give a combined stocking rate of 2.5 ha per AUM. The stocking rate for the year was 1.8 ha per AUM in the deer-only field and 1.0 ha per AUM in the dual-grazed field. The heifers were maintained in a holding area with alfalfa hay when not in the field.

An attempt was made to balance the number of observations among animals. About 1.5 observations were made weekly on each deer and 3 observations were made weekly on each heifer. The observations were made either in early morning or late evening during 1-hour intervals. Each observation consisted of counting the number of bites taken from each forage species. Bites were not adjusted to weight per bite, as Regelin et al. (1974) reported negligible differences between percentage of bites and percentage of weight converted from bites.

The canopy and herbage cover of trees and shrubs greater than $1.5 \mathrm{~m}$ in height was estimated by line intercepts along 14 transects, each 160 $\mathrm{m}$ long (seven in each field). The transects extended perpendicular to the average slope and were $15 \mathrm{~m}$ apart. The percent ground cover of all forages less than $1.5 \mathrm{~m}$ in height was estimated to the nearest $5 \%$ within $1 \mathrm{~m}^{2}$ plots placed every $10 \mathrm{~m}$ along the transects. For species with less than 5\% ground cover the estimates were made to the nearest $1 \%$ with the arid of a grid. A $t$-test was used to compare the cover of each species between fields.

\section{Year Two}

The fields and treatments remained the same as in Year One. Although no feeding observations were made on cattle, two shorthorn cows were periodically placed into the dual-grazed field to maintain the grazing effect. The observations were scparated into two periods to remove some variation resulting from changing availability. The periods were: June 20 to July 15 (1) and July 17 to August 16 (2). Originally two deer were assigned to each of the two fields. Unfortunately, one deer escaped, leaving only a single animal for the dual-grazed field.

For both years the number of bites from each forage species was converted to a percent of the total bites counted in each observation. Diets between fields and animals were compared in the first year, using a dissimilarity index (Hansen et al. 1973) and, in both years, a 
$t$-test on important spccics. The data were normalized with the arc sine square root transformation prior to the latter analysis. Dietary overlap was calculated according to Anthony and Smith (1977).

Supplemental Studies

Forb and Shrub Use by Cattle

Forage selection was estimated at 15 sites with varying grazing pressures. Grazing pressure was defined as the proportion of pinegrass grazed. The sites were classified into one of three classes according to grazing pressure. The classes, and their proportion of pinegrass grazed, were: low, $0-30 \%$; moderate, 31 to 60 : and high, 61 to $90 \%$. The survey was made with belt transects, 1-m wide, which were oriented to sample the greatest variety of forages on each site. A stem count of shrubs and trees, below $1.5 \mathrm{~m}$ in height, was made within the belt and a plant count of forbs was made within $1 \mathrm{~m}^{2}$ plots placed at 10 $m$ intervals along the transects. Selection was estimated as the proportion of stems/plants utilized. A stem was considered utilized if any portion had been browsed.

A one-way analysis of variance was used to infer utilization differences among the three grazing classes and Duncan's multiple range test to define differences among means. These analyses were made with data normalized with the arc sine square root transformation.

\section{Forage Selection by Fawns}

Forage selection by four mule deer fawns was studied on a 2-ha site from July 17 to September 1 . The animals were released individually, with limited restriction, and feeding was observed for half-hour intervals. Diets were determined from total bite counts for each observation, and summarized for all animals over the entire period.

The percent ground cover of herbaceous and woody forage was estimated to the nearest $5 \%$ within 21 plots each $1-\mathrm{m}^{2}$ in size and spaced $10 \mathrm{~m}$ apart along two transects. The transects were oriented to sample the areas most often used by the fawns.

\section{Results and Discussion}

The sites selected for study were in the lower region of the deer and cattle summer range. Although the relative importance of plant communities to deer on this range was not known, the sites were believed to be preferred areas to both deer and cattle by virtue of the forage composition.

\section{Direct Interaction Study}

The species composition of the fields was similar with a few exceptions (Table 1). The largest difference was with pinegrass. This was not considered important to the study since deer did not use this species. Perhaps the most important differences were in the cover of rose (Rosa spp.) and fireweed (Epilobium (ingustifolium), which were selected by both deer and cattle.

\section{Year One}

Individual observations of deer were made on 37 occasions and of cattle on 43 occasions. The average number of bites counted per observation was 417 for deer and 795 for cattle.

Dissimilarity indices in this study ranged from 0 , for identical diets, to about 20 , for completely dissimilar diets. The upper value varied depending on the number of species tested in the analysis. The method compared dietary variation between a control (within group) and a test (between groups). As such, any source that contributed variation affected the analysis. In the present study, the average control indices ranged from 9 to 14 and the text index from 9 to 18. Most control indices for the deer groups were high, indicating large dietary variation within individual animals.

According to this method, differences among individual deer were not significant $(P<0.10)$ when they foraged on the same field. This was true for among the groups of four deer in Period One or between individuals of both groups in Period Two.
Table 1. Composition of important species (\% ground cover) at Opax in fields grazed only by deer and simultaneously by deer and cattle.

\begin{tabular}{|c|c|c|}
\hline \multirow[b]{2}{*}{ Plant type and species } & \multicolumn{2}{|c|}{$\%$ ground cover } \\
\hline & Deer-only field & Dual-grazed field \\
\hline Number of samples & 114 & 82 \\
\hline \multicolumn{3}{|l|}{ Grass-like } \\
\hline Calamagrostis rubescens & 35.0 & $16.8+$ \\
\hline Other grasses & 0.7 & 13.0 \\
\hline Carex spp. & 2.9 & 3.3 \\
\hline \multicolumn{3}{|l|}{ Forbs } \\
\hline Comandra livida & 4.7 & $1.4+$ \\
\hline Epilobium angustifolium & 1.9 & 1.0 \\
\hline Fragaria glauca & 2.8 & 2.6 \\
\hline Linnaea borealis & 14.1 & $6.8+$ \\
\hline Pyrola spp. & 3.5 & 3.0 \\
\hline Trifolium repens & 1.2 & 2.5 \\
\hline \multicolumn{3}{|l|}{ Shrubs } \\
\hline Alnus sitchensis & 0.3 & $6.5+$ \\
\hline Rosa spp. & 5.6 & $3.4+$ \\
\hline Rubus idaeus & 5.2 & 4.8 \\
\hline Salix spp. & 1.6 & 1.4 \\
\hline Shepherdia canadensis & 2.3 & 3.8 \\
\hline \multicolumn{3}{|l|}{ Trees } \\
\hline Picea engelmanni & 1.8 & 2.9 \\
\hline Populus tremuloides & 2.7 & 1.0 \\
\hline Pseudotsuga menziesii & 5.7 & 4.0 \\
\hline
\end{tabular}

+ Average significantly different at $P<0.05$.

Individual cattle diets differed in Period One but not in Period Two $(P<0.10)$.

The greatest differences occurred between cattle and deer in the second period when the difference between the average test index and the average control index was 9 . The difference was the same when the deer diets were compared from either field. The next largest differences were in the cattle diets between periods (4), between cattle and deer in Period One (2), and between periods for deer (2). All differences were significant at $P<0.01$. A notable comparison not significant $(P<0.05)$ was in the diets of deer between fields in Period Two.

Although the diets of deer and cattle differed according to the dissimilarity index, it is evident from a species analysis (Table 2) that competition did occur. The problem must be viewed as one of degree rather than of absolutes.

In Period One, cattle selected an equal proportion of grasses and forbs (Table 2 ). The forbs were represented primarily by clover (Trifolium repens). In Period Two the proportion of grasses increased and forbs decreased. Although the proportion of shrubs did not change between periods, the major species selected changed from willow (Salix spp.) to raspberry (Rubus leucodermis) (Table 2).

Deer selected primarily forbs in Period One, consisting largely of clover (Table 2). Shrubs were also a major component of their diet. In Period Two the proportion of forbs decreased while shrubs increased. The change was affected by selection of less clover and more spirea (Spiraea lucida) and raspberry.

Deer diets did not change to the same extent between periods as did cattle diets. Willow and fireweed continued to be selected in nearly the same proportion as in Period One. Clover, on the other hand, was selected considerably less in Period Two than in the first but contributed a larger proportion to the deer diet than to the cattle diet. The deer switched to a greater selection of shrubs in Period Two, presumably to compensate for a reduced 
Table 2. Forage selection (\% bites, $\overline{\mathbf{x}} \pm \mathrm{SE}$ ) by deer and cattle with no species interaction (Period One) and with grazing by deer imposed in the cattle field (Period Two).

\begin{tabular}{|c|c|c|c|c|c|}
\hline \multirow[b]{4}{*}{ Plant type and species } & \multicolumn{5}{|c|}{ Diet composition (\%) } \\
\hline & & & \multirow[b]{3}{*}{ Cattle dual use } & \multicolumn{2}{|c|}{ Period 2} \\
\hline & \multicolumn{2}{|c|}{ Period 1} & & & \\
\hline & Cattle single use ${ }^{1}$ & Deer single use & & dual use & single use \\
\hline Number of samples & 15 & 15 & 28 & 13 & 9 \\
\hline Grass (all) & $40.9 \pm 1.2 c^{2}$ & $3.2 \pm 0.7 \mathrm{~b}$ & $60.2 \pm 0.8 \mathrm{~d}$ & $1.1 \pm 0.4 \mathrm{a}$ & $1.4 \pm 0.6 \mathrm{a}$ \\
\hline $\begin{array}{l}\text { Forbs } \\
\text { Epilobium angustifolium } \\
\text { Fragaria glauca } \\
\text { Linnaea borealis } \\
\text { Taraxacum officinale }\end{array}$ & $\begin{array}{l}8.7 \pm 1.1 \mathrm{c} \\
0.5 \pm 0.2 \mathrm{~b} \\
0.7 \pm 0.4 \mathrm{a} \\
2.8 \pm 0.6 \mathrm{bc}\end{array}$ & $\begin{array}{r}5.8 \pm 0.3 \mathrm{bc} \\
5.7 \pm 0.7 \mathrm{c} \\
0 \mathrm{a} \\
5.2 \pm 0.7 \mathrm{c}\end{array}$ & $\begin{array}{l}0.8 \pm 0.3 \mathrm{a} \\
0.1 \pm 0.1 \mathrm{a} \\
4.2 \pm 0.4 \mathrm{~b} \\
0.4 \pm 0.2 \mathrm{a}\end{array}$ & $\begin{array}{l}2.8 \pm 0.5 \mathrm{~b} \\
5.0 \pm 0.8 \mathrm{c} \\
0.6 \pm 0.3 \mathrm{a} \\
1.2 \pm 0.4 \mathrm{ab}\end{array}$ & $\begin{array}{l}8.9 \pm 1.0 \mathrm{c} \\
7.4 \pm 0.9 \mathrm{c} \\
0.3 \pm 0.3 \mathrm{a} \\
1.5 \pm 0.7 \mathrm{ab}\end{array}$ \\
\hline $\begin{array}{l}\text { Trifolim repens } \\
\text { Other } \\
\text { Total forbs }\end{array}$ & $\begin{array}{l}28.8 \pm 1.3 c \\
0.2 \\
41.7 \pm 1.4 b\end{array}$ & $\begin{array}{l}39.1 \pm 1.3 \mathrm{c} \\
1.2 \\
62.8 \pm 1.4 \mathrm{c}\end{array}$ & $\begin{array}{l}3.1 \pm 0.6 \mathrm{a} \\
2.6 \\
11.2 \pm 0.6 \mathrm{a}\end{array}$ & $\begin{array}{l}7.6 \pm 0.8 b \\
12.3 \\
29.5 \pm 1.3 b\end{array}$ & $\begin{array}{l}12.6 \pm 1.4 b \\
10.0 \\
40.7 \pm 1.6 b\end{array}$ \\
\hline $\begin{array}{l}\text { Shrubs } \\
\text { Acer glabrum } \\
\text { Alnus sitchensis } \\
\text { Rosa } \text { spp. } \\
\text { Rubus idaeus } \\
\text { Salix spp. } \\
\text { Spiraea lucida } \\
\text { Other } \\
\text { Total shrubs }\end{array}$ & $\begin{array}{l}0 \\
0.4 \pm 0.3 \mathrm{~b} \\
0.1 \pm 0.1 \mathrm{a} \\
0.2 \pm 0.2 \mathrm{a} \\
5.9 \pm 0.7 \mathrm{~b} \\
0.5 \pm 0.3 \mathrm{a} \\
0.1 \\
7.2 \pm 0.8 \mathrm{a}\end{array}$ & $\begin{array}{r}0 \\
2.0 \pm 0.6 \mathrm{~b} \\
10.4 \pm 1.0 \mathrm{c} \\
1.0 \pm 0.2 \mathrm{a} \\
10.8 \pm 1.0 \mathrm{~b} \\
1.2 \pm 0.4 \mathrm{a} \\
8.5 \\
33.9 \pm 1.4 \mathrm{~b}\end{array}$ & $\begin{array}{l}0 \\
0 \mathrm{a} \\
0.5 \pm 0.2 \mathrm{~b} \\
5.5 \pm 0.5 \mathrm{~b} \\
0.6 \pm 0.2 \mathrm{a} \\
0.7 \pm 0.2 \mathrm{a} \\
3.6 \\
10.9 \pm 0.6 \mathrm{a}\end{array}$ & $\begin{array}{c}3.2 \pm 0.8 \\
0.6 \pm 0.3 \mathrm{~b} \\
17.5 \pm 1.1 \mathrm{c} \\
15.2 \pm 1.3 \mathrm{~b} \\
7.7 \pm 0.8 \mathrm{~b} \\
9.5 \pm 1.2 \mathrm{~b} \\
14.8 \\
68.5 \pm 1.3 \mathrm{c}\end{array}$ & $\begin{array}{l}0 \\
4.2 \pm 1.1 \mathrm{~b} \\
10.4+1.0 \mathrm{c} \\
12.0 \pm 1.5 \mathrm{~b} \\
6.4 \pm 1.2 \mathrm{~b} \\
8.9 \pm 1.4 \mathrm{~b} \\
8.7 \\
50.6 \pm 1.7 \mathrm{c}\end{array}$ \\
\hline Trees (all) & $0 \mathrm{a}$ & $0.1 \pm 0.2 \mathrm{a}$ & $0.2 \pm 0.1 \mathrm{a}$ & $0.1 \pm 0.2 \mathrm{a}$ & $5.6 \pm 1.0 \mathrm{~b}$ \\
\hline $\begin{array}{l}\text { Non-vascular } \\
\text { Lichen }\end{array}$ & $10.2 \pm 1.3 \mathrm{ab}$ & $0 \mathrm{a}$ & $17.5 \pm 0.8 \mathrm{~b}$ & $0.8 \pm 0.4 a$ & $1.7 \pm 0.8 \mathrm{a}$ \\
\hline
\end{tabular}

1 Term refers to the occupation of field by either deer, cattle or both.

$\because$ a to d: Averages with the same letter do not differ significantly $(P<0.05)$.

availability of forbs (Table 2).

To evaluate the effect that cattle grazing had on deer diets, it is necessary to compare deer diets in the deer-only and dual-grazing fields in Period Two. Few significant $(P<0.05)$ differences occurred in species selection between deer of the two fields (Table 2). Considering only the forages that were heavily used by both deer and cattle, (ie. fireweed, clover, willow, and rose) the following inferences can be made. Deer in the dual-grazed field selected about half the proportion of fireweed and clover as did the deer in the deer-only field. This may be the result of the interspecific competition. Deer selected similar proportions of willow in both fields despite considerable use by cattle. Although willow selection by cattle declined from Period One to Period Two, willow selection by deer did not. It appears that interspecific competition for willow was more severe for cattle than it was for deer. Evidently deer were more capable of fully utilizing shrubs because of their smaller mouth parts than were cattle.

An interpretation of the Competitive Exclusion Principle (Krebs 1972) may be used to summarize these inferences. When food was not limiting, forage selection specificity was not great and food niche was much broader. When the resources became limiting, however, specificity increased and a food niche narrowed. For deer the niche was dominated by shrubs, while for cattle it was dominated by grass.

The effects of forcing animals into a specific diet are hard to assess. On the one hand it could be argued that a high stocking rate provides the best food niche separation and would assure a fairly high, ecologically efficient use of forage since there would be only a few unused forages. On the other hand, the basic diet of the forced niche may be nutritionally inferior to the

unforced diet, leading one to assume that animal productivity would be greater with low stocking rates but forage use efficiency would be lower.

\section{Year Two}

Cattle grazing continued in the second year at the Opax although their diets were not studied. Observations on deer began on June 20 and extended to August 16. A total of 47 observations were made with an average of 615 bites counted for each observation.

The most numerous dietary changes in deer diets occurred between fields in Period One and between periods in the deer-only field (Table 3). In Period One, deer selected a majority of forbs in the deer-only field and more shrubs in the dual-grazed field. Willow accounted for most of the shrub differences and dandelion (Taraxacum officinale) for most of the forb differences. There were no important differences in Period Two between the deer diets of either field.

The diet changes between periods one and two in the deer-only field was toward one more similar to the diet in the dual-grazed field. Forb selection decreased while shrub selection increased. The most noteworthy changes between periods in the dual-grazed field was a decline in willow selection. First period dietary differences between the two fields reinforces the observation made the previous year that cattle use alters the deer diet by removing forbs and forcing deer to select more shrubs.

\section{Supplemental Studies}

\section{Forb and Shrub Use by Cattle}

The degree of use on most shrub and forb species increased linearly with increased grazing intensity (Table 4). Utilization 
Table 3. Forage selection ( $\%$ bites $\mathrm{x} \pm \mathrm{SE}$ ) by deer in the second year at Opax, in two periods and in two fields (single use and dual use).'

\begin{tabular}{|c|c|c|c|c|}
\hline \multirow[b]{3}{*}{ Plant type and species } & \multicolumn{4}{|c|}{ Diet composition (\%) } \\
\hline & \multicolumn{2}{|c|}{ Period 1} & \multicolumn{2}{|c|}{ Period 2} \\
\hline & Singe use & Dual use & Single use & Dual use \\
\hline Number of samples & 15 & 8 & 12 & 9 \\
\hline Grass (all) & $0.5 \pm 0.3 \mathrm{a}^{2}$ & $0.2 \pm 0.2 \mathbf{a}$ & $0.3 \pm 0.2 \mathrm{a}$ & $0.1 \pm 0.1 \mathrm{a}$ \\
\hline \multicolumn{5}{|l|}{ Forbs } \\
\hline Comandra livida & $2.6 \pm 1.9 \mathrm{a}$ & $1.2 \pm 1.2 \mathrm{a}$ & $26.1 \pm 7.9 b$ & $9.6 \pm 5.5 \mathrm{ab}$ \\
\hline Epilobium angustifolium & $11.4 \pm 2.6 \mathrm{~b}$ & $7.5 \pm 3.8 \mathrm{ab}$ & $1.8 \pm 0.5 \mathrm{a}$ & $4.0 \pm 1.3 \mathrm{ab}$ \\
\hline Fragaria glauca & $7.1 \pm 1.8 \mathrm{a}$ & $3.6 \pm 2.4 \mathrm{a}$ & $6.7 \pm 2.1 \mathrm{a}$ & $2.3 \pm 0.6 \mathrm{a}$ \\
\hline Taraxac'um officinale & $38.8 \pm 6.4 b$ & $17.8 \pm 8.1 \mathrm{a}$ & $13.8 \pm 5.2 \mathrm{a}$ & $6.6 \pm 2.6 a$ \\
\hline Trifolium repens & $6.7 \pm 2.4 a$ & $2.1 \pm 1.3 \mathrm{a}$ & $2.8 \pm 1.3 \mathrm{a}$ & $8.7 \pm 3.1 \mathrm{a}$ \\
\hline Other & 2.7 & 10.8 & 4.9 & 23.5 \\
\hline Total forbs & $69.4 \pm 4.4 b$ & $43.0 \pm 9.7 \mathrm{a}$ & $56.1 \pm 5.6 \mathrm{a}$ & $54.7 \pm 7.0 \mathrm{a}$ \\
\hline \multicolumn{5}{|l|}{ Shrubs } \\
\hline Alnus sitchensis & $0.3 \pm 0.1 \mathrm{a}$ & $5.2 \pm 3.4 b$ & $4.5 \pm 2.1 b$ & $59.9 \pm 3.5 b$ \\
\hline Cormus canadensis & $0.3 \pm 0.4 \mathrm{a}$ & $0.4 \pm 0.4 a$ & $1.3 \pm 0.5 \mathrm{ab}$ & $3.6 \pm 1.2 \mathrm{~b}$ \\
\hline Cornus stolonifera & $0.3 \pm 0.2 \mathrm{ab}$ & $0 \mathbf{a}$ & $3.3 \pm 1.9 \mathrm{c}$ & $0.8 \pm 0.4 \mathrm{bc}$ \\
\hline Ribes spp. & $1.2 \pm 0.3 \mathrm{a}$ & $1.2 \pm 0.8 \mathrm{a}$ & $5.7 \pm 1.3 \mathrm{~b}$ & $5.9 \pm 2.8 \mathrm{ab}$ \\
\hline Rosaspp. & $17.6 \pm 3.7 \mathrm{a}$ & $18.6 \pm 10.8 \mathrm{a}$ & $14.3 \pm 3.8 \mathrm{a}$ & $6.1 \pm 1.5 \mathrm{a}$ \\
\hline Rubus idaeus & $3.1 \pm 1.1 b$ & $1.1 \pm 1.1 \mathrm{a}$ & $4.6+2.1 b$ & $3.7 \pm 1.9 b$ \\
\hline Salixspp. & $5.8 \pm 2.6 \mathrm{a}$ & $26.4 \pm 8.5 b$ & $2.6 \pm 0.7 \mathrm{a}$ & $8.2 \pm 2.8 \mathrm{a}$ \\
\hline Spiraea lucida & $1.0 \pm 0.4 \mathrm{a}$ & $0.5 \pm 0.2 \mathrm{a}$ & $2.0 \pm 0.7 \mathrm{a}$ & $1.3 \pm 1.0 \mathrm{a}$ \\
\hline Other & 0 & 2.2 & 3.7 & 7.6 \\
\hline Total shrubs & $29.6 \pm 4.4 \mathrm{a}$ & $55.6 \pm 9.6 \mathrm{~b}$ & $42.0 \pm 5.5 b$ & $43.7 \pm 7.2 b$ \\
\hline Trees (all) & $0.3 \pm 0.1 \mathrm{a}$ & $1.2 \pm 0.7 \mathbf{a}$ & $1.2 \pm 0.3 \mathrm{a}$ & $1.6 \pm 0.7 \mathrm{a}$ \\
\hline Non-vascular (all) & $0.2 \pm 0.1 \mathrm{a}$ & $0 \mathbf{a}$ & $0.4 \pm 0.3 \mathrm{a}$ & $0.5 \pm 0.3 \mathrm{a}$ \\
\hline
\end{tabular}

' Teru refers to the occupation of field by deer or by both cattle and deer.

$\because$ a to $c$ : Averages with the same letter do not differ significantly $(P<0.05)$.

of Saskatoon serviceberry (Amelanchier alnifolia), aspen (Populus tremuloides), and willow was greater than that of grass when use of the latter was low. However, as grazing pressure increased, the degree of use on grass became greater than the degree of use on shrubs. The decreasing use of shrubs appearcd to be the result of increased difficulty in obtaining residual forage. This may be caused by a barriere effect from previously browsed stems. Other shrubs and trees utilized in minor proportions at all grazing intensities were: bearberry (Arcto- staphylos uva-ursi), juniper (Juniperus spp.), lodgepole pine (Pinus contorta), Douglasfir, and soopalallie (Shepherdia (anadensis). Spirea was utilized to approximately the same degree as grass, thus suggesting incidental selection.

\section{Forage Selection by Fawns}

The vegetative ground cover was dominated by grass. Shrub species present, in order of decreasing cover, were: snowberry (Symphoricarpos albus), Douglasfir, rose, Saskatoon service-

Table 4. Percent utilization (\% of available stems) of forb and shrub species by cattle at Opax in relation to three classes of grazing intensity (\% cover grazed) on pinegrass.

\begin{tabular}{|c|c|c|c|c|c|c|}
\hline \multirow[b]{3}{*}{ Species } & \multicolumn{6}{|c|}{ Grazing intensity class $(\%)$} \\
\hline & \multicolumn{2}{|c|}{$\begin{array}{c}\text { Low } \\
0-30\end{array}$} & \multicolumn{2}{|c|}{$\begin{array}{c}\text { Moderate } \\
31-60\end{array}$} & \multicolumn{2}{|c|}{$\begin{array}{l}\text { High } \\
61-90\end{array}$} \\
\hline & Avg \% util. & No. of stems counted & Avg \% until. & No. of stems counted & Avg \% util. & No. of stems counted \\
\hline Achillea millefolium & 6 & 36 & 8.4 & 32 & 16.0 & 94 \\
\hline Alnus rubra & 2.2 & 117 & 28.2 & 257 & 37.1 & 140 \\
\hline \multirow{2}{*}{\multicolumn{7}{|c|}{ Arctostaphylos }} \\
\hline & & & & & & \\
\hline uva-ursi & $0.1 \mathrm{a}$ & 940 & $3.2 \mathrm{a}$ & 715 & $2.4 \mathrm{a}$ & 225 \\
\hline Arnica cordifolia & 5.0 & 189 & 1.5 & 160 & 14.3 & 21 \\
\hline Aster spp. & 13.9 & 56 & 35.1 & 108 & 33.1 & 14 \\
\hline Berberis repens & 0 & 18 & 9.2 & 209 & 48.4 & 17 \\
\hline Fragaria glauca & $2.1 \mathrm{a}$ & 134 & $1.4 \mathrm{a}$ & 207 & $10.0 \mathrm{a}$ & 92 \\
\hline Populus tremuloides & $20.6 a$ & 167 & $35.4 \mathrm{a}$ & 567 & $42.3 \mathrm{a}$ & 150 \\
\hline Ribes spp. & - & - & $5.8 \mathrm{a}$ & 145 & $32.2 \mathrm{a}$ & 157 \\
\hline Rosa spp. & $14.7 \mathbf{a a}$ & 882 & $32.3 a$ & 1248 & $53.9 \mathrm{~b}$ & 1592 \\
\hline Rubus leucodermis & - & - & 20.0 & 44 & 53.1 & 53 \\
\hline Rubus parviflorus & - & - & 4.4 & 100 & 45.1 & 152 \\
\hline Salix spp. & $30.6 a$ & 829 & $57.5 \mathrm{a}$ & 846 & $60.8 \mathrm{a}$ & 525 \\
\hline Spiraea lucida & $10.4 a$ & 156 & $56.7 \mathrm{~b}$ & 420 & $68.6 b$ & 74 \\
\hline Symphoricarpos albus & 0 & 66 & 51.7 & 205 & 76.5 & 435 \\
\hline Taraxacum officinale & $1.8 \mathrm{a}$ & 121 & 10.5 & 257 & $4.3 a$ & 424 \\
\hline
\end{tabular}

' a to b: Averages of $\%$ utilization followed by the same letter in rows are not significantly $(P<0.05)$ different. Those rows without letters have one or more averages derived from less than three sites. 
Table 5. Forage selection (\% diet) by four mule deer fawns on a Pass Lake summer range, (diet measured from 17 July to 1 September in 124 observations for a total of 14144 bites).

\begin{tabular}{lc}
\hline Plant type and species & Diet $(\%)$ \\
\hline Grass (all) & $1.3 \pm 0.2 \pm$ \\
Forbs & \\
$\quad$ Aster spp. & $0.7 \pm 0.2$ \\
Astragalus spp. & $5.1 \pm 0.8$ \\
Fragaria glauca & $0.8 \pm 0.2$ \\
Taraxacum officinale & $9.8 \pm 1.0$ \\
Other & 1.6 \\
& \\
Total forbs & $18.0 \pm 1.2$ \\
& \\
Shrubs and trees & \\
Amelanchier alnifolia & $14.7 \pm 1.4$ \\
Populus tremuloides & $3.3 \pm 0.4$ \\
Pseudotsuga menziesii & $1.6 \pm 0.2$ \\
Rosa spp. & $42.4 \pm 1.9$ \\
Salix spp. & $1.9 \pm 0.4$ \\
Shepherdia canadensis & $5.6 \pm 0.8$ \\
Spiraea lucida & $3.0 \pm 0.4$ \\
Symphoricarpos albus & $5.8 \pm 0.5$ \\
Other & 1.6 \\
Total shrubs and trees & $79.9 \pm 1.3$ \\
& \\
Non-vascular (all) & $0.8 \pm 0.2$ \\
&
\end{tabular}

$' \mathrm{x} \pm \mathrm{SE}_{m}$

berry, spirea, Oregon grape (Berberis repens), vetch (Astragalus spp.), strawberry (Fragaria glauca), dandelion, peavine (Lathyrus spp.), and northern bedstraw (Galium boreale). The percent ground cover, from the first to last species, ranged from 1.2 to $0.2 \%$.

The fawns selected primarily shrubs, trees, and forbs (Table $5)$. Of the individual species, rose was most often selected. Saskatoon serviceberry and dandelion were next in importance followed by snowberry, soopalallie, and vetch.

The effect of interaction between cattle and fawns on the latter is not known although it is more likely related to competition with the doe. The fawns may be getting milk for 3 months (Moen 1973) and this will reduce their requirement for solid food. They are, however, capable of prehending and ruminating forages soon after birth and are presumably capable of extracting some nutrients. Wood et al. (1961) successfully weaned fawns when they were 5 to 7 weeks old.

The diets of fawns were higher in shrubs and lower in forbs than the diets of adult deer and included some forages not used by the adults (Table 5). These selection differences may be influenced by varying availability of forages, but may also indicate less selectivity by fawns and differing food preferences. Tucker et al. (1977) found some differences in preference between young and adult deer when both were fed clipped shrubs during winter.
All woody species selected by the fawns, with the exception of Douglasfir and soopalallie, were also utilized by cattle (Table 4). Similarly, cattle will utilize all the forb species that the fawns selected. The important question is whether cattle leave enough forage for the fawns and whether the forage meets the nutritional requirements of fawns for optimum growth and development. This question has not been answered; however, some generalizations can be made. First, cattle may leave $20 \%$ or more the available stems on the shrubs even at high grazing intensities (Table 4). Since the fawns can be more selective than cattl, at least some of the residual material is available to them. Second, the energy requirement of fawns may be only one-third that of adults; consequently forage requirements are substantially less. This is particularly true for the suckling fawn. Third, deer occupy a greater variety of habitats than do cattle. The probability of occupying areas lightly grazed by cattle is high on a moderately stocked range. Unfortunately, the question raised above cannot be conclusively answered except through more research.

\section{Literature Cited}

Anthony, R.G., and N.S. Smith. 1977. Ecological relationships between mule deer and white-tailed deer in southeastern Arizona. Ecol. Monogr. 47:255-277.

Edgerton, P.J. 1972. Big game use and habitat changes in recently logged mixed conifer forest in northeastern Oregon. Western Proc., 52nd Annu. Conf. West. Ass. of State Game and Fish Commissioners. Portland, Ore., p. 239-246.

Gates, B.R. 1968. Deer food production in certain seral stages of the coast forest. M.Sc. Thesis. Univ. of British Columbia. $106 \mathrm{p}$.

Hansen, R.M., D.G. Peden, and R.W. Rice. 1973. Discerned fragments in feces indicate diet overlap. J. Range Manage. 28: 43-47.

Harris, R.W. 1951. Use of aerial photographs and subsampling in range in ventories. J. Range Manage. 4:270-278

Julander, O. 1955. Deer and cattle range relations in Utah. Forest Sci. 1:130-139.

Krebs, C.J. 1972. Ecology. The Experimental Analysis of Distribution and Abundance. Harper and Row Publ, New York. 694 p.

McLean, A. 1970. Plant communities of the Similkameen Valley, British Columbia, and their relationships to soils. Ecol. Monogr. 40:403-423.

McLean, A., and W. Willms. 1977. Cattle diets and distribution on spring-fall and summer ranges near Kamloops, British Columbia. Can. J. Anim. Sci. 57:81-92.

Moen, A.N. 1973. Wildlife Ecology: An Analytical Approach. W.H. Freeman and Co., San Francisco. $458 \mathrm{p}$.

Regelin, W.L., O.C. Wallmo, J. Nagy, and D.R. Dietz. 1974. Effects of logging on forage values for deer in Colorado. J. Forestry. 75: 282-285.

Skovlin, J.N., R.W. Harris, G.S. Strickler, and G.A. Harrison. 1976. Effects of cattle grazing methods on ponderosa pine-bunchgrass range in the Pacific Northwest. U.S. Dep. Agr. Forest Serv. Tech. Bull. 1531. 40 p.

Tisdale, E.W., and A. McLean. 1957. The Douglasfir zone of southern Interior British Columbia. Ecol. Monogr. 27:247-266.

Tucker, R., A. McLean, and D.E. Waldern. 1977. Relative preference by mule deer for six shrubs from ranches near Kamloops, British Columbia. Can. J. Anim. Sci. 57:375-377.

W allmo, O.C., Regelin, W.L. and D.W. Reichert. 1972. Forage use by mule deer relative to logging in Colorado. J. Wildl. Manage. 36: 1025-1033.

Wood, A.J., H.C. Nordan, and I. McT Cowan. 1961. The care and management of wild ungulates for experimental purposes. J. Wildl. Manage. 25: 295-302. 